\title{
Neurocognitive function declines are reversible following migraine headache in college students
}

\author{
MT Moore ${ }^{1 *}$, T Covassin $^{2}$, KA Pfeiffer ${ }^{2}$, RE Norris ${ }^{2}$, RL Jensen ${ }^{1}$, CF Branta ${ }^{2}$ \\ From The European Headache and Migraine Trust International Congress \\ London, UK. 20-23 September 2012
}

\section{Introduction}

Computerized testing of neurocognitive function yields an accurate and reliable assessment [1]. There is little research on short-term effects of migraine headaches on neurocognitive function or their cognitive recovery patterns[2].

\section{Purpose/background/objective}

The purpose of this study was to investigate neurocognitive function and recovery patterns in college students who incur migraine headaches compared to college students who do not.

\section{Methods}

Volunteers (ages 18-29) completed computerized neurocognitive baseline (B) testing. Forty-four migraineurs incurring a migraine $(\mathrm{M})$ were matched to 44 nonmigraine (NM) controls for sex, age and education level. Verbal and visual memory, processing speed and reaction time were measured at 24 hours, 48 hours and 7 days post migraine.

\section{Results}

Repeated measures ANOVAs revealed declines in neurocognitive function of migraineurs in verbal memory [mean diff(md)(24hr-B) $\mathrm{M}=-1.59 \pm 7.82, \mathrm{NM}=1.19 \pm 7.69$; $=.045$ ], visual memory [md (24hr-B) $\mathrm{M}=-4.70+15.61$, $\mathrm{NM}=3.05+10.94 ; \mathrm{p}=.041)$, and reaction time $[\mathrm{md}(24 \mathrm{hr}-\mathrm{B})$ $\mathrm{M}=.02 \pm .09, \mathrm{NM}=-.01 \pm .04$.

\section{Author details \\ ${ }^{1}$ Northern Michigan University, USA. ${ }^{2}$ Michigan State University, USA.}

Published: 21 February 2013

Northern Michigan University, USA

Full list of author information is available at the end of the article

\section{References}

1. Iverson GL, Lovell MR, Collins MW: Validity of ImPACT for measuring attention and processing speed following sports-related concussion. Journal of Clinical and Experimental Neuropsychology 2005, 27:683-689.

2. Farmer $K$, Cady R, Bleiberg J, Reeves D: A pilot study to measure cognitive efficiency during migraine. Headache 2001, 40:657-661.

doi:10.1186/1129-2377-14-S1-P74

Cite this article as: Moore et al: Neurocognitive function declines are reversible following migraine headache in college students. The Journal of Headache and Pain 2013 14(Suppl 1):P74

\section{SpringerOpen $^{\odot}$}

(c) 2013 Moore et al; licensee Springer. This is an Open Access article distributed under the terms of the Creative Commons Attribution License (http://creativecommons.org/licenses/by/2.0), which permits unrestricted use, distribution, and reproduction in any medium, provided the original work is properly cited.
Submit your manuscript to a SpringerOpen ${ }^{\circ}$ journal and benefit from:

- Convenient online submission

- Rigorous peer review

- Immediate publication on acceptance

- Open access: articles freely available online

- High visibility within the field

- Retaining the copyright to your article

Submit your next manuscript at $\mathbf{p}$ springeropen.com 